\title{
Assessment of Heavy Metal Concentrations in Seawater in the Coastal Areas around Daerah Istimewa Yogyakarta Province, Indonesia
}

\author{
Andrea Sumarah Asih ${ }^{1}$, Akhmad Zamroni², Wahyudiansyah Alwi ${ }^{3}$, Saurina Tua Sagala ${ }^{3}$ and Adam Sukma \\ Putra $^{4, *}$ \\ Departemen of Civil Engineering, Institut Teknologi Nasional Yogyakarta, Indonesia \\ Departement of Geological Engineering, Institut Teknologi Nasional Yogyakarta, Indonesia \\ Departmen of Mining Engineering, Institut Teknologi Nasional Yogyakarta, Indonesia \\ Geophysics Division, Department of Physics, Faculty of Mathematics and Natural Science, Universitas Gadjah Mada, Indonesia \\ Correspondence: adamsukmaputra@ugm.ac.id
}

Received:

16 September 2021

Accepted:

13 November 2021

Published:

28 February 2022

\begin{abstract}
Due to anthropogenic influences that can cause heavy metal pollution in the aquatic environment, it is essential to know the amounts of heavy metals in coastal seawater to assess the potential damage of the ecosystem. The purpose of this study is to assess heavy metal concentrations $(\mathrm{Cd}, \mathrm{Pb}, \mathrm{Cu}$, and $\mathrm{Zn})$ in seawater in the coastal areas around Daerah Istimewa Yogyakarta Province, Indonesia. This study will be useful for the assessment and monitoring of marine pollution around the study area. A total of 9 water samples were collected in the close of nine types of coastal land use, namely mangrove ecosystem, tourist attraction, airport, harbor, mining area, bare land, shrimp pond, agricultural land, and settlement around Daerah Istimewa Yogyakarta Province in June 2021. The concentrations of $\mathrm{Cd}, \mathrm{Cu}$, and $\mathrm{Zn}$ were not detected, concentrations were below the limit of detection. The $\mathrm{Pb}$ concentrations at all sampling locations did not comply with seawater quality standards for ports, marine tourism, or marine biota based on the Ministry of Environment Decree No. 51, the year 2004 regulation. The source of $\mathrm{Pb}$ in the study area was estimated from anthropogenic and natural sources. The anthropogenic sources were corrosion of junk metal items, automobile traffic, resuspension of lead-contaminated soil dust, boat navigation, painting of boats, a coking coal transport service, fishing port, the supply of fuel, fertilizer, fuel for mining equipment, and transportation of mining activities. While the natural sources were the concentration of $\mathrm{Pb}$ contained in iron sand (a part of Quarterly Alluvium) eroded due to waves and wind then mixed in seawater.
\end{abstract}

Keywords: Contamination; Seawater; Ecosystem; Pollution; Soil

\section{Introduction}

Water pollution is one of the major concerns facing society in the twenty-first century. Water contaminants are produced as a result of industrialization, climate change, and urbanization (Zamora-Ledezma et al. 2021). Water pollution is caused by expanding population activities and the need to offer goods and services that rely on water as a crucial resource. Heavy metal contamination of water is a major worry for humanity, although there is little global research on the subject (Kumar et al. 2019; Awadh and Ahmed, 2013). Heavy metal contamination has garnered a lot of attention throughout

DOI: $\underline{10.46717 / \text { igj.55.1B.2Ms-2022-02-18 }}$ 
the world due to how quickly they accumulate in the natural environment. Heavy metals enter aquatic environments through direct emissions or surface runoff from natural sources such as atmospheric inputs and geologic weathering, as well as human activities like agricultural and industrial sewage discharge (Zhang et al. 2017). Marine pollution has a long history dating back to the dawn of human civilization along coastlines. Mining, industrial activity, and coastal and noncoastal urbanization have all contributed to an increase in marine pollution. Furthermore, new and more complicated contaminants have appeared. The degradation, loss of marine and coastal ecosystems as a result of anthropogenic activities is a global issue that is the focus of extensive management efforts (Chen \& Chen, 2020). Toxic heavy metals harm marine species variety and ecosystems, posing health hazards, and having negative consequences for humans. Heavy metal consumption, on the other hand, is helpful in modest doses; for example, $\mathrm{Zn}$ and $\mathrm{Cu}$ are necessary for human health, especially for maintaining proper physiological function (Hao et al. 2019). Heavy metals have always been present in large quantities in seawater, and the high concentrations found in some fish may have resulted from the discharge of industrial waste containing heavy metals into the marine environment (Baltas, et al. 2017). In the last decade, a few studies on heavy metal concentrations in seawater have been published (Y1lmaz \& Sadikoglu, 2011; Balasubramanian, T. 2012; Naser, 2013; Fu et al. 2014; Dong et al. 2016; Baltas et al. 2017; Li et al. 2017; Sankar et al. 2018; Al-Absi et al. 2019; Arikibe \& Prasad, 2020; Youssef et al. 2021). Due to its poisonous qualities, heavy metal contamination could cause a variety of difficulties for various marine ecosystems, as well as accumulating in marine species (Al-Jaberi \& Al-Dabbas, 2016). Heavy metals in seawater must be investigated to monitor and evaluate marine pollution. Due to anthropogenic influences that can cause heavy metal pollution in the aquatic environment, it is essential to know the amounts of heavy metals in coastal seawater to assess the potential damage to the ecosystem. Monitoring heavy metals in coastal seawaters could be used to determine the extent of pollution caused by human activities (Yücel \& Çam, 2019). The south coast of Daerah Istimewa Yogyakarta (DIY) Province is an area on the south side bordered by the Indian Ocean. Due to the sand on this beach contains a high concentration of metal minerals, it has the potential to be exploited. Local people had been working hard to convert the sandy soil, which had extremely limited nutrient availability, into viable farming land (Nurcholis \& Mulyanto, 2017). As a result, heavy metal pollution must be controlled to research the pollution status of heavy metals, particularly under the influence of human activities. Furthermore, some mining activities are carried out in that site using the amalgamation technique, which entails combining the sand powder with mercury to create an amalgam (alloy) that is used as a gold binder. As a result of mining activities, tailing waste is discharged into the subterranean and rivers, contaminating the soil, river mud (Rachman et al. 2017), and seawater, particularly if it enters the ocean via surface runoff. The results were useful in regulating human activities, such as adjusting land use planning in coastal areas, improving the regional biological environment, and increasing the value of ecosystem services offered (Hu et al. 2020). The purpose of this study is to assess heavy metal concentrations $(\mathrm{Cd}, \mathrm{Pb}, \mathrm{Cu}$, and $\mathrm{Zn})$ in seawater in the coastal areas around the study area. This study will be useful for the assessment and monitoring of marine pollution around DIY Province, Indonesia.

\section{Geology of the Study Area}

The study area is located in the coastal areas around DIY Province, south of Java Island, Indonesia. Java Island's southern coast is part of the Indonesia archipelago, which faces the Indian Ocean subduction zone immediately (Widianto \& Damen, 2014). The coast is a long, straight stretch of land that mostly faces the south-southwest. Sand dune, karst hill land, swale, and alluvial plains may all be found along DIY Province's coast. Throughout the year, the rivers that run to the coast have a water dynamic (Triyatmo et al. 2018). Low undulating sand dunes go for around 1 to 2 kilometers inland along the coastline. The west side of the bathymetry slopes sharply down to the ocean, whereas the eastern 
side slopes more gradually. The shoreline as a whole, however, has nearly uniform bathymetric and ground topography (Ohira et al. 2012). In the past, the south coast of DIY Province has been used for ponds, resulting in the degradation of mangroves. The majority of farm activities are currently inactive, and farmers have begun to transfer their agricultural efforts to rice fields and other seasonal crops (Afsholnissa et al. 2019). Geologically, the study area is located on the southern side of the Yogyakarta Quadrangle (Fig.1), in the Kulonprogo Regency's coastal area, DIY Province. Andesite, Old Andesite Formation (OAF) (Upper Oligocene), Sentolo Formation (Lower Miocene to Middle Miocene), and Quarterly Alluvium are the exposed formations in the study area, from oldest to youngest. Each Tertiary volcano body in the Kulon Progo Mountains has andesite in its central-proximal facies. As a result of tectonic forces' deformation, it has become fragile. As a result, if a tectonic force exists, the rocks are more prone to break (Widagdo et al. 2018). Andesite volcanic breccia, lapilli breccia, tuff, lapilli tuff, andesite lava flow fragments, volcanic sandstone fragments, and agglomerates make up the OAF. The Sentolo Formation is made up of limestone, marl sandstones, marl tuff-boarded conglomerate, and a glass tuff. It is made up of volcanic material that was formed during the creation of volcanic OAFs. These rocks evolved into a well-layered limestone rich in Foraminifera as they progressed upwards. The majority of alluvial deposits found along large rivers and coastal plains make up Quarterly Alluvium. Gravel, sand, silt, and clay make up these deposits. The alluvial plain is made up of volcanic rock alluvial soil. Alluvial deposits can be found on the east, west, and south sides of the Kulonprogro plain. The alluvial sand deposits along the coast in the south of the Kulonprogro region (Widagdo et al. 2016; Zamroni et al., 2021b). In addition, there are two types of sand sediment in DIY Province. Gray sand, which is a mixture of quartz, coral reef fragments, and mafic minerals, is type 1 , whereas black sand, which is dominated by iron sand and has a low quartz mineral content, is type 2 (Noviadi, 2020; Zamroni et al. 2021a). The water sampling locations are part of the Quarterly Alluvium that has two types of sand sediment; type 1 and type 2 .

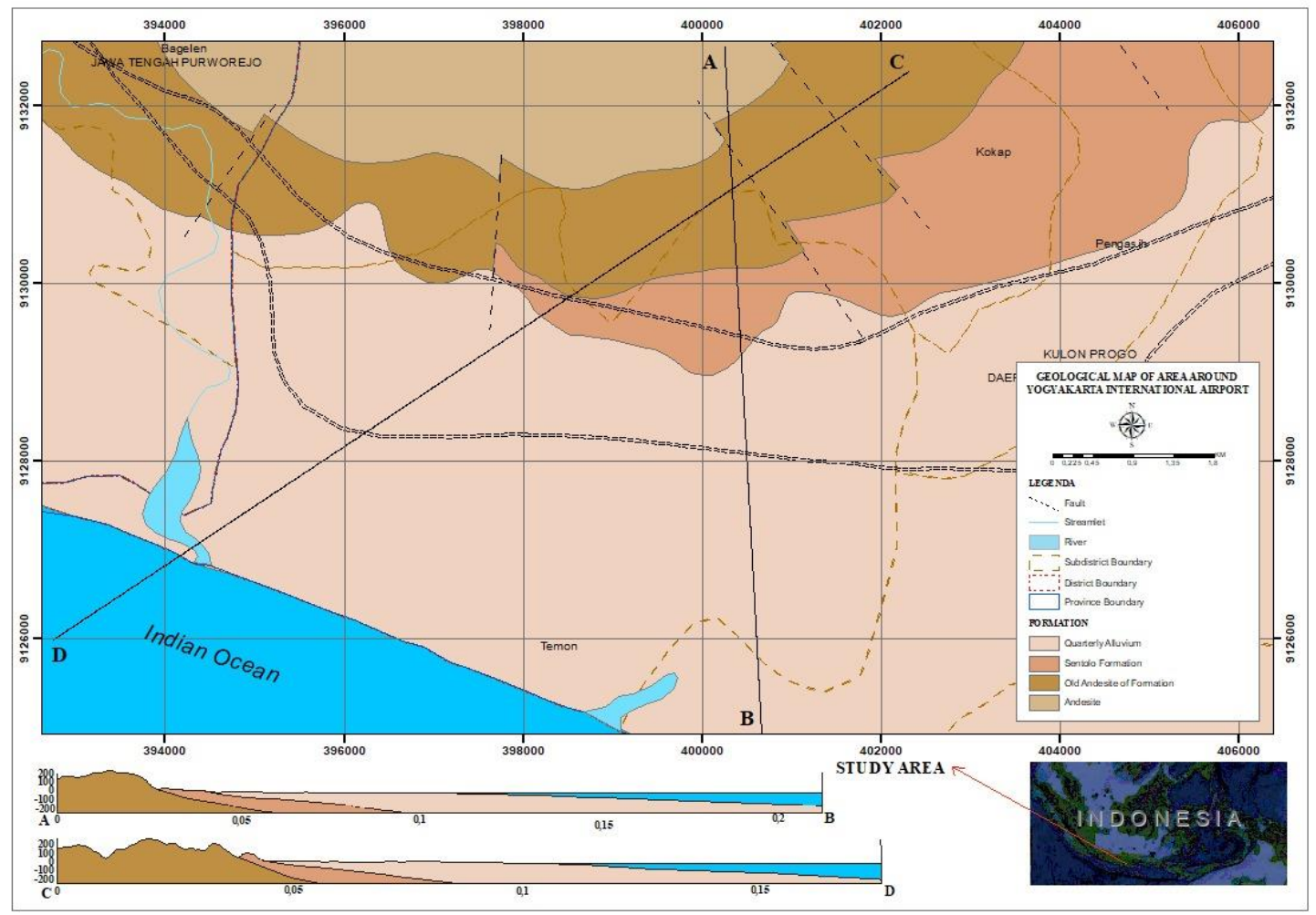

Fig.1. Geological map of the study area (Modified from Rahardjo et al.1995) 


\section{Materials and Methods}

The research method is inspired by $\mathrm{Hu}$ et al. (2020) that conducted a study influence of different land-use types on hydrochemistry and heavy metals in surface water. A total of 9 water samples were collected along with the coastal areas around DIY Province, Indonesia in June 2021 (Fig.2).

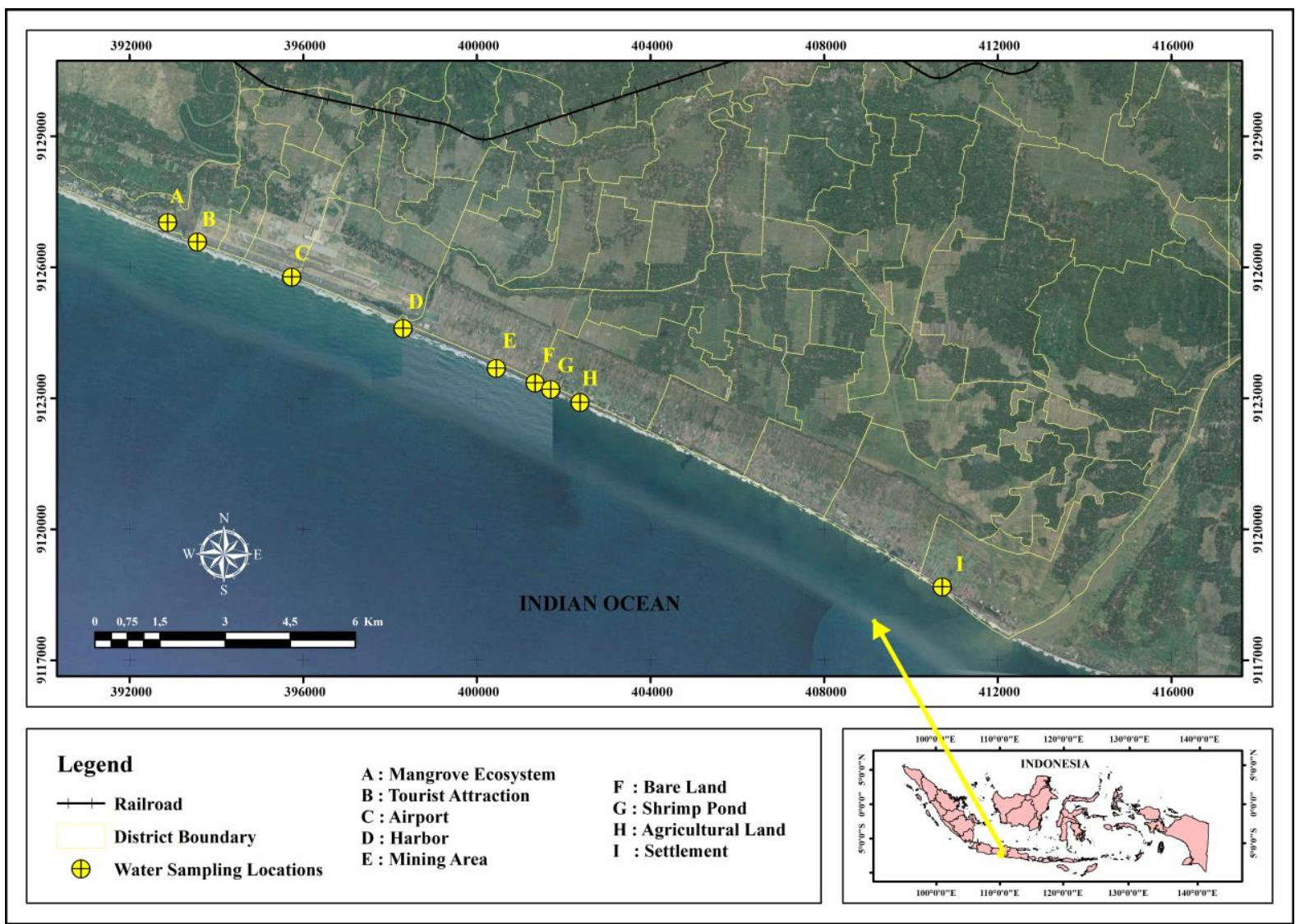

Fig.2. Sampling distribution map of the study area

The period was the dry season. Samples were collected by using polyethylene bottles with a volume of $1000 \mathrm{ml}$ at a depth of $50 \mathrm{~cm}$ from the sea surface in the close of nine types of coastal land use, namely mangrove ecosystem, tourist attraction, airport, harbor, mining area, bare land, shrimp pond, agricultural land, and settlement. The samples for dissolved traces metals were acidified with high-purity $\mathrm{HNO}_{3}$ and then stored in a refrigerator before analysis. Finally, the concentrations of $\mathrm{Cd}, \mathrm{Pb}$, $\mathrm{Cu}$, and $\mathrm{Zn}$ were determined by using Atomic Absorption Spectrophotometer (AAS) in the instrumentation, basic physics, and basic chemistry laboratory, Universitas Islam Indonesia. The data analysis was done by comparing the results of laboratory analysis with the seawater quality standards based on the Minister of Environment Decree No. 51 the year 2004, which is concerned with Seawater Quality Standards that relate to the lives of marine biota (Kementerian Negara Lingkungan Hidup, 2004).

\section{Results and Discussion}

\subsection{Heavy Metal Concentrations in Seawater}

The results of the analysis of heavy metal concentrations at the study area are shown in Table 1. 
Table 1. Heavy metal concentration at the study area

\begin{tabular}{lcccc}
\hline Sampling locations (Land use types) & $\mathbf{C d}(\mathbf{m g} / \mathbf{l})$ & $\mathbf{P b}(\mathbf{m g} / \mathbf{l})$ & $\mathbf{C u}(\mathbf{m g} / \mathbf{l})$ & $\mathbf{Z n}(\mathbf{m g} / \mathbf{l})$ \\
\hline Mangrove ecosystem (A) & $<0.035$ & 0.612 & $<0.234$ & $<0.214$ \\
Tourist attraction (B) & $<0.035$ & 0.767 & $<0.234$ & $<0.214$ \\
Airport (C) & $<0.035$ & 1.005 & $<0.234$ & $<0.214$ \\
Harbor (D) & $<0.035$ & 0.881 & $<0.234$ & $<0.214$ \\
Mining area (E) & $<0.035$ & 0.788 & $<0.234$ & $<0.214$ \\
Bare land (F) & $<0.035$ & 0.994 & $<0.234$ & $<0.214$ \\
Shrimp pond (G) & $<0.035$ & 1.160 & $<0.234$ & $<0.214$ \\
Agricultural land (H) & $<0.035$ & 0.860 & $<0.234$ & $<0.214$ \\
Settlement (I) & $<0.035$ & 1.160 & $<0.234$ & $<0.214$ \\
\hline
\end{tabular}

According to Table 1., the concentrations of $\mathrm{Cd}, \mathrm{Cu}$, and $\mathrm{Zn}$ were not detected, i.e. concentrations were below the limit of detection (LOD). The concentration of $\mathrm{Pb}$ from the highest to the lowest, respectively, was in the types of land use of shrimp pond, settlement, airport, bare land, harbor, agricultural land, mining area, tourist attraction, and mangrove ecosystem. $\mathrm{Pb}$ in the marine environment has been found to come from sources like new construction land and urban land, automobile exhaust, mining, coal burning, metal smelting, paint (Hu et al. 2020), anthropogenic sources as repainting of boats, boat navigation, the supply of fuel and tourist activities (Nour, 2019), and ascribed to the influx of river water including effluents from a range of industrial plants strewn over the riverside (Lü et al. 2015). Shrimp pond is not a source of heavy metal pollution, but the heavy metal content in seawater will contaminate shrimp pond. The source of $\mathrm{Pb}$ in the study area around the shrimp pond and bare land was estimated to come from riverine drainage. In the settlement, airport, and tourist attraction at the study area, the source of $\mathrm{Pb}$ was estimated to be from the corrosion of junk metal items, automobile traffic, and resuspension of lead-contaminated soil dust. In the harbor at the study area, the source of $\mathrm{Pb}$ was estimated to be from boat navigation, painting of boats, a coking coal transport service, fishing port, and the supply of fuel. $\mathrm{PbO}, \mathrm{PbS}, \mathrm{PbSO}_{4}$, and $\mathrm{PbO}^{*} \mathrm{PbSO}_{4}$ from smelting, $\mathrm{Pb}_{3} \mathrm{O}_{4}, \mathrm{PbCrO}_{4}$, $\mathrm{PbCO}_{3}$ from paint, and $\mathrm{Pb}\left(\mathrm{C}_{2} \mathrm{H}_{5}\right)_{4}$ from $\mathrm{Pb}\left(\mathrm{CH}_{3}\right)_{4}$ in tetramethyl lead (TML) and tetraethyl lead (TEL), all gasoline additives, are all anthropogenic sources of $\mathrm{Pb}$. $\mathrm{Pb}$ halides such as $\mathrm{PbBrCl}, \mathrm{PbBr}$, $(\mathrm{PbO})_{2} \mathrm{PbBr}_{2}$, and $\mathrm{Pb}(\mathrm{OH}) \mathrm{Br}$ are found in automobile exhaust. These compounds prefer to create more stable $\mathrm{PbSO} 4$ when they react with neutral and acid sulfate droplets in the environment. $\mathrm{Pb}$ oxides can be produced by photochemical breakdown, and exhaust particles can be transformed into oxides, sulfates, and carbonates in soils. Each form of $\mathrm{Pb}$ behaves differently in soils, depending on a range of soil processes and features. In the agricultural land at the study area, the source of $\mathrm{Pb}$ was estimated to be fertilizer. Heavy metals can be found in phosphorus fertilizers and other chemical fertilizers since they are impurities in natural materials and minerals. $\mathrm{Pb}$ values of $5.6-17.2 \mathrm{mg} / \mathrm{kg}$ were detected in phosphorus fertilizers and rock phosphate. The source of $\mathrm{Pb}$ in the mining area at the study area was estimated to be from fuel for mining equipment and transportation of mining activities. While the concentration of $\mathrm{Pb}$ in the mangrove ecosystem at the study area was the lowest. It was estimated that the mangrove plant can immobilize, extract and translocate heavy metals although it was limited (Cheraghi et al. 2012; Wu et al. 2014; Egendorf et al. 2020).

Natural sources of heavy metals in atmospheric particles include crustal minerals and volcanic eruptions (Wan et al. 2016). $\mathrm{Pb}$ is derived from both natural and anthropogenic sources (Yona et al. 2020). $\mathrm{Pb}$ is formed naturally as parent rocks decompose, but it can also accumulate from anthropogenic sources such as lead-zinc smelters, traffic exhaust, dumps, and other locations that receive industrial and household lead, such as paints and batteries (Lin et al. 2013). Pb is a bluish-gray metal in the IV group of 
the periodic table, in period 6. It is found in nature as a mineral with other elements such as sulfides with $\mathrm{S}\left(\mathrm{PbS}, \mathrm{PbSO}_{4}\right)$ or oxides with oxygen $\left(\mathrm{PbCO}_{3}\right)$ (Mishra et al. 2019). Pb concentrations in the study area were most likely due to lithological causes as well. Iron sand from the DIY province's coastline region, which has $\mathrm{Cu}$ and $\mathrm{Pb}$ elements over the usual content found in most rocks. $\mathrm{Pb}$ was derived from metallic minerals vanadinite $\left(\mathrm{Pb}_{5}\left(\mathrm{VO}_{4}\right)_{3} \mathrm{Cl}\right)$ in iron sand in the study area (Nurcholis \& Mulyanto, 2017). From the previous experiment, the adsorption of $\mathrm{Pb}$ ions concentration in the iron sand was 151 to $509 \mathrm{mg} / \mathrm{kg}$, while the $\mathrm{Cu}$ was 24.3 to $46.3 \mathrm{mg} / \mathrm{kg}$ (Setiadi et al., 2016). It indicates that the $\mathrm{Pb}$ content in seawater in the study area was also estimated from $\mathrm{Pb}$ contained in iron sand (a part of Quarterly Alluvium) eroded due to waves and wind then mixed in seawater. However, further research on the source of heavy metal, whether due to natural or anthropogenic factors, needs to be investigated further using Multivariate Statistical Analysis (Baluch et al. 2019). The sketch of the study result is shown in Fig.2.

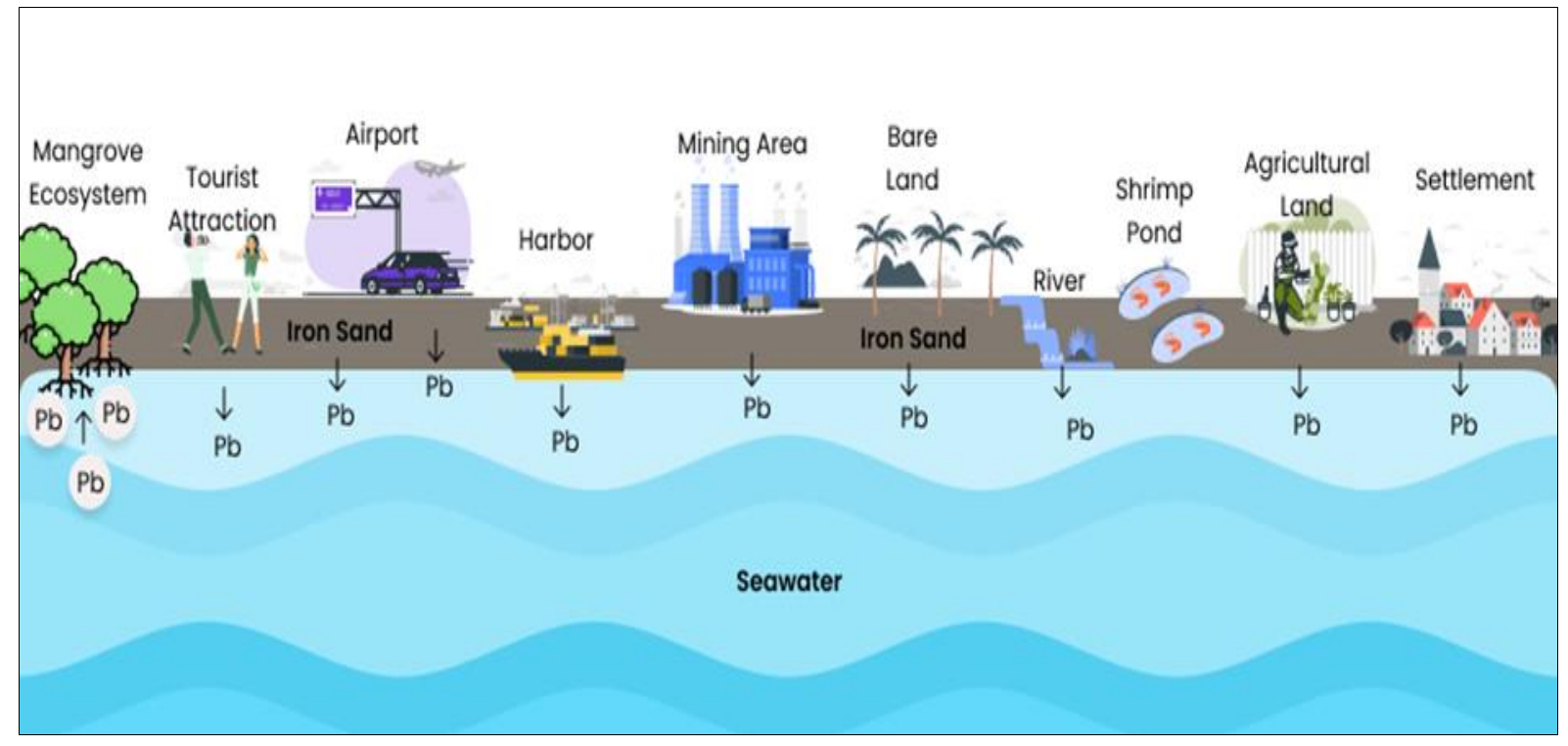

Fig.2. The sketch of heavy metal concentration in seawater in the study area.

\subsection{Comparison with National Standard}

The Ministry of Environment Decree No. 51, the year 2004 stipulated seawater quality standards for some use, namely ports, marine tourism, and marine biota. The $\mathrm{Pb}$ concentration quality standards for each seawater use are shown in Table 2.

Table 2. The $\mathrm{Pb}$ concentration quality standards for each seawater use.

\begin{tabular}{lc}
\hline Seawater use & $\mathrm{Pb}$ concentration $(\mathrm{mg} / \mathrm{l})$ \\
\hline Ports & 0.1 \\
Marine tourism & 0.005 \\
Marine biota & 0.008 \\
\hline
\end{tabular}

According to the Ministry of Environment Decree No. 51, the year 2004, the Pb concentrations at all sampling locations did not comply with seawater quality standards for ports, marine tourism, or marine biota. Therefore, the government must take action to prevent the excessive accumulation of heavy metals in the seawater by monitoring and controlling heavy metal waste generated from human activities. In addition, management policies must be conducted to improve seawater quality. 


\section{Conclusions}

The concentrations of $\mathrm{Cd}, \mathrm{Cu}$, and $\mathrm{Zn}$ were not detected, concentrations were below the limit of detection. The $\mathrm{Pb}$ concentrations at all sampling locations did not comply with seawater quality standards for ports, marine tourism, or marine biota based on the Ministry of Environment, Decree No. 51, the year 2004 regulation. The source of $\mathrm{Pb}$ in the study area was estimated from anthropogenic and natural sources. The anthropogenic sources were corrosion of junk metal items, automobile traffic, resuspension of lead-contaminated soil dust, boat navigation, painting of boats, a coking coal transport service, fishing port, the supply of fuel, fertilizer, fuel for mining equipment, and transportation of mining activities. While the natural sources were the concentration of $\mathrm{Pb}$ contained in iron sand (a part of Quarterly Alluvium) eroded due to waves and wind then mixed in seawater. Therefore, the government must take action to prevent the excessive accumulation of heavy metals in the seawater by monitoring and controlling heavy metal waste generated from human activities. However, further research on the source of heavy metal, whether due to natural or anthropogenic factors, needs to be investigated further using multivariate statistical analysis.

\section{Acknowledgements}

We thank Institut Teknologi Nasional Yogyakarta (ITNY), Indonesia who support this research funding. We appreciate students of ITNY that took samples for this study. We thank you for the best sketch of this study made by Ayu Atikha Reinaty. The authors are very grateful to the reviewers, Editor in Chief Prof. Dr. Salih M. Awadh, the Secretary of Journal Mr. Samir R. Hijab, and the Technical Editors for their great efforts and valuable comments.

\section{References}

Afsholnissa, S., Hernawan, E., \& Lastini, T., 2019. Land cover change and land use suitability analyses of coastal area in Bantul district, Yogyakarta, Indonesia. Biodiversitas, 20(5),1475-1481.

Al-Absi, E., Manasrah, R., Abukashabeh, A., \& Wahsha, M., 2019. Assessment of heavy metal pollutants at various sites along the Jordanian coastline of the Gulf of Aqaba, Red Sea. International Journal of Environmental Analytical Chemistry, 99(8), 726-740.

Al-Jaberi, M. H., \& Al-Dabbas, M. A. 2016. Evaluation of Iraqi coasts using littoral and marine bivalve shells. Iraqi Geological Journal, 39-49(2), 16-33.

Arikibe, J. E., \& Prasad, S., 2020. Determination and comparison of selected heavy metal concentrations in seawater and sediment samples in the coastal area of Suva, Fiji. Marine Pollution Bulletin, 157(June), 111157.

Awadh, S.M. and Ahmed, R.M., 2013. Hydrochemistry and pollution probability of selected sites along the Euphrates River. Western Iraq Arab Journal Geoscience, 6, 2501-2518.

Baltas, H., Kiris, E., \& Sirin, M. 2017. Determination of radioactivity levels and heavy metal concentrations in seawater, sediment and anchovy (Engraulis encrasicolus) from the Black Sea in Rize, Turkey. Marine Pollution Bulletin, 116(1-2), 528-533.

Baltas, H., Sirin, M., Dalgic, G., Bayrak, E. Y., \& Akdeniz, A., 2017. Assessment of metal concentrations (Cu, Zn, and $\mathrm{Pb}$ ) in seawater, sediment and biota samples in the coastal area of Eastern Black Sea, Turkey. Marine Pollution Bulletin, 122(1-2), 475-482.

Baluch, M. A., Hashmi, H. N., \& Yu, L., 2019. Investigating the impact of anthropogenic and natural sources of pollution on quality of water in Upper Indus Basin (UIB) by using multivariate statistical analysis. Journal of Chemistry,

Chen, Q., \& Chen, P., 2020. Changes in the heavy metals and petroleum hydrocarbon contents in seawater and surface sediment in the year following artificial reef construction in the Pearl River Estuary, China. Environmental Science and Pollution Research, 27(6), 6009-6021.

Cheraghi, M., Lorestani, B., \& Merrikhpour, H., 2012. Investigation of the effects of phosphate fertilizer application on the heavy metal content in agricultural soils with different cultivation patterns. Biological trace element research, 145(1), 87-92. 
Dong, Y., Rosenbaum, R. K., \& Hauschild, M. Z. 2016. Assessment of metal toxicity in marine ecosystems: comparative toxicity potentials for nine cationic metals in coastal seawater. Environmental Science and Technology, 50(1), 269-278.

Egendorf, S. P., Groffman, P., Moore, G., \& Cheng, Z., 2020. The limits of lead (Pb) phytoextraction and possibilities of phytostabilization in contaminated soil: a critical review. International Journal of Phytoremediation, 22(9), 916-930.

Fu, J., Wang, H., Billah, S. M. R., Yu, H., \& Zhang, X., 2014. Heavy metals in seawater, sediments, and biota from the coastal area of Yancheng City, China. Environmental Toxicology and Chemistry, 33(8), 1697-1704.

Hao, Z., Chen, L., Wang, C., Zou, X., Zheng, F., Feng, W., Zhang, D., \& Peng, L., 2019. Heavy metal distribution and bioaccumulation ability in marine organisms from coastal regions of Hainan and Zhoushan, China. Chemosphere, 226, 340-350.

Hu, J., Long, Y., Zhou, W., Zhu, C., Yang, Q., Zhou, S., \& Wu, P., 2020. Influence of different land use types on hydrochemistry and heavy metals in surface water in the lakeshore zone of the Caohai wetland, China. Environmental Pollution, 267, 115454.

Kementerian Negara Lingkungan Hidup., 2004. Keputusan Menteri Negara Lingkungan Hidup Nomor 51 Tahun 2004 Tentang Baku Mutu Air Laut. Jakarta: Kementerian Negara Lingkungan Hidup. [in Indonesian]

Kumar, V., Parihar, R. D., Sharma, A., Bakshi, P., Singh Sidhu, G. P., Bali, A. S., Karaouzas, I., Bhardwaj, R., Thukral, A. K., Gyasi-Agyei, Y., \& Rodrigo-Comino, J., 2019. Global evaluation of heavy metal content in surface water bodies: A meta-analysis using heavy metal pollution indices and multivariate statistical analyses. Chemosphere, 236, 124364.

Li, H., Lin, L., Ye, S., Li, H., \& Fan, J., 2017. Assessment of nutrient and heavy metal contamination in the seawater and sediment of Yalujiang Estuary. Marine Pollution Bulletin, 117(1-2), 499-506.

Lin, Y. C., Chang-Chien, G. P., Chiang, P. C., Chen, W. H., \& Lin, Y. C. (2013). Multivariate analysis of heavy metal contaminations in seawater and sediments from a heavily industrialized harbor in Southern Taiwan. Marine Pollution Bulletin, 76(1-2), 266-275.

Lü, D., Zheng, B., Fang, Y., Shen, G., \& Liu, H., 2015. Distribution and pollution assessment of trace metals in seawater and sediment in Laizhou Bay. Chinese Journal of Oceanology and Limnology, 33(4), 1053-1061.

Mishra, S., Bharagava, R. N., More, N., Yadav, A., Zainith, S., Mani, S., \& Chowdhary, P., 2019. Heavy metal contamination: an alarming threat to environment and human health. Environmental Biotechnology: For Sustainable Future, 103-125.

Naser, H. A., 2013. Assessment and management of heavy metal pollution in the marine environment of the Arabian Gulf: A review. Marine Pollution Bulletin, 72(1), 6-13.

Nour, H. E. S., 2019. Distribution, ecological risk, and source analysis of heavy metals in recent beach sediments of Sharm El-Sheikh, Egypt. Environmental Monitoring and Assessment, 191(9),1-12.

Noviadi, Y., Setiady, D., 2020. Sedimentasi pasir sepanjang pantai Kulon Progo, Daerah Istimewa Yogyakarta. Jurnal Geologi Kelautan, 18(1).

Nurcholis, M., \& Mulyanto, D., 2017. Study on the residue resulted from the metallic minerals separations to the coastal iron-sand of Yogyakarta Indonesia. International Journal of Applied Engineering Research, 12(15), 5218-5225.

Ohira, W., Honda, K., \& Harada, K., 2012. Reduction of tsunami inundation by coastal forests in Yogyakarta, Indonesia: A numerical study. Natural Hazards and Earth System Science, 12(1), 85-95.

Balasubramanian, T., 2012. Heavy metal contamination and risk assessment in the marine environment of arabian sea, along the Southwest Coast of India. American Journal of Chemistry, 2(4), 191-208.

Rachman, R. M., Karisma, E. D., \& Trihadiningrum, Y., 2017. Stabilization/solidification of mercury contaminated soil of traditional gold mining in Kulon Progo Yogyakarta, Indonesia using a mixture of Portland cement and tras soil. ARPN Journal of Engineering and Applied Sciences, 12(22), 6380-6387.

Rahardjo, W., Sukandarrumidi, \& Rosidi, H.M.D., 1995. Peta Geologi Lembar Yogyakarta, Pusat Penelitian dan Pengembangan Geologi, Bandung

Sankar, R., Sachithanandam, V., Thenmozhi, C., Sivasankar, R., Sai Elangovan, S., Yuvaraj, E., Marimuthu, N., Mageswaran, T., Sridhar, R., \& Ananthan, G., 2018. Integrated assessment of heavy metal contamination in water, sediments and marine organisms from Southeast Coast of India. Indian Journal of Geo-Marine Sciences, 47(6), 1274-1289. 
Setiadi, E. A., Sebayang, P., Ginting, M., Sari, A. Y., Kurniawan, C., Saragih, C. S., \& Simamora, P., 2016. The synthesization of $\mathrm{Fe}_{3} \mathrm{O}_{4}$ magnetic nanoparticles based on natural iron sand by co-precipitation method for the use of the adsorption of $\mathrm{Cu}$ and $\mathrm{Pb}$ ions. Journal of Physics, 776 (1), 1.

Triyatmo, B., Rustadi, R., \& Priyono, S. B., 2018. Characteristics and environmental carrying capacities of coastal area in Yogyakarta Special Region for aquaculture. IOP Conference Series: Earth and Environmental Science, 139(1).

Wan, D., Han, Z., Yang, J., Yang, G., \& Liu, X., 2016. Heavy metal pollution in settled dust associated with different urban functional areas in a heavily air-polluted city in North China. International Journal of Environmental Research and Public Health, 13(11).

Widagdo, A., Pramumijojo, S., Harijoko, A., \& Setiawan, A., 2016. Preliminary overview of the character , patterns and styles of the geologic structure of Kulon Progo Mountains Area and its potential as a source of the geological structural damage. Jogja Earthquake in Reflection, 41-46.

Widagdo, A., Pramumijoyo, S., Harijoko, A., \& Setiyanto, A., 2018. Fault lineaments control on disaster potentials in Kulon Progo Mountain Area-Central Java-Indonesia. In MATEC, 229, 03008. EDP Sciences.

Widianto, A., \& Damen, M., 2014. Determination of coastal belt in the disaster prone area: a case study in the coastal area of Bantul Regency, Yogyakarta, Indonesia. Indonesian Journal of Geography, 46(2), 125.

Wu, Q., Tam, N. F. Y., Leung, J. Y. S., Zhou, X., Fu, J., Yao, B., Huang, X., \& Xia, L. 2014. Ecological risk and pollution history of heavy metals in Nansha mangrove, South China. Ecotoxicology and Environmental Safety, 104(1), 143-151.

Y1lmaz, S., \& Sadikoglu, M., 2011. Study of heavy metal pollution in seawater of Kepez harbor of Canakkale (Turkey). Environmental Monitoring and Assessment, 173(1-4), 899-904.

Yona, D., Vernandes, D., Kasitowati, R. D., \& Sari, S. H. J., 2020. Spatial distribution and contamination assessment of lead $(\mathrm{Pb})$ in the seawater and surface sediments of the coastal area of prigi bay, trenggalek, East Java. Jurnal Ilmiah Perikanan Dan Kelautan, 12(1), 140-148.

Youssef, M., El-Sorogy, A., Al-Kahtany, K., \& Madkour, H., 2021. Status of trace metals in surface seawater of Sharm Al-Kharrar lagoon, Saudi Arabia. Arabian Journal of Geosciences, 14(9).

Yücel, Y., \& Çam, A. R., 2019 Assessment of industrial pollution effects in coastal seawater (Northeastern Mediterranean Sea) with chemometric approach. International Journal of Environmental Analytical Chemistry, 1-18.

Zamora-Ledezma, C., Negrete-Bolagay, D., Figueroa, F., Zamora-Ledezma, E., Ni, M., Alexis, F., \& Guerrero, V. H., 2021. Heavy metal water pollution: A fresh look about hazards, novel and conventional remediation methods. Environmental Technology and Innovation, 22(March), 101504.

Zamroni, A, Sugarbo, O., Trisnaning, P. T., \& Prasetya, H. N. E., 2021a. Seawater intrusion prone areas around Yogyakarta International Airport: a geological approach. IOP Conference Series: Earth and Environmental Science, 782(2), 022006.

Zamroni, A., Sugarbo, O., Trisnaning, P. T., Sagala, S. T., \& Putra, A. S., 2021b. Geochemical approach for seawater intrusion assessment in the area around Yogyakarta International Airport, Indonesia. The Iraqi Geological Journal, 1-11.

Zhang, Y., Chu, C., Li, T., Xu, S., Liu, L., \& Ju, M., 2017. A water quality management strategy for regionally protected water through health risk assessment and spatial distribution of heavy metal pollution in 3 marine reserves. Science of the Total Environment, 599-600, 721731. 